\title{
総腓骨神経刺激症状を呈した膝窩囊腫の一例
}

\author{
田原 隼* 中 村 英 一 * 鬼木 泰 成* 岡 元 信 和* \\ 田中 あづさ* 廣 瀬 隼 ${ }^{*}$ 武 藤 和 彦* 水田 博 志*
}

\section{Compressive Neuropathy of the Common Peroneal Nerve due to Popliteal Cyst: A Case Report}

\author{
Jun Tahara*, Eiichi Nakamura*, Yasunari Oniki*, \\ Nobukazu Okamoto*, Azusa Tanaka*, Jun Hirose*, \\ Kazuhiko Muto*, and Hiroshi Mizuta*
}

【目的】膝窩囊腫は外来診療においてよく遭遇する疾患であるが, 神経刺激症状を伴うものはまれである. 我々は総腓骨神経刺激症状を伴った膝窩囊腫の一例を経験したので若干の文献的考察を加え報告する.

【症例】 45 歳女性, 約 2 ケ月前より左膝後外側に腫瘤を触知し, 伸展位で明らかな神経脱落症状はみら れなかつたが，最大屈曲時に下腿外側のしびれが増強した。左膝のレントゲンは明らかな異常は認められ なかった. MRI で膝窩部に $5 \times 3 \times 3 \mathrm{~cm}$ の腫瘤性病変を認め, 腫瘤は膝窩筋腱と腓腹筋外側頭との間か ら，外側側副勒帯まで連続して認められ，総腓骨神経は腫瘤に前後を挟まれるように存在していた．関節 造影検査にて関節腔との交通は認められなかつたため, 直視下囊腫摘出手術を施行し, 病理所見より膝窩 囊腫と診断した. 術後 6 ケ月の時点で再発は認めず, 復職している.

Popliteal cysts occur commonly, but those causing compressive neuropathy are unusual. We report a case with compressive neuropathy of the common peroneal nerve by a popliteal cyst. A 45-year old woman with a two month history of an asymptomatic popliteal mass in her left lateral knee visited our outpatient clinic due to persistent symptoms. Physical examination revealed an approximately $4 \mathrm{~cm}$ soft elastic mass on the postlateral aspect of her left knee and she complained lateral cruris numbness during full flexion of her knee. Radiographs were normal, but magnetic resonance imaging showed a cystic mass measuring $5 \times 3 \times 3 \mathrm{~cm}$ in the popliteal fossa. That cyst was located between the popliteal tendon and the lateral head of the gastrocnemius through to the fibular collateral ligament and the common peroneal nerve went along the interval. Arthrography showed no communication between the cyst and joint. We performed surgical excision of the cyst directly, and the histologic diagnosis was a politeal cyst. Postoperatively she had no numbness during flexion of her knee.

Key words : popliteal cyst (膝窩囊腫), Baker cyst (ベーカー囊腫), common peroneal nerve (総 腓骨神経), neuropathy (神経障害)

\section{は じめ に}

膝窩囊腫は外来診療においてよく遭遇する疾患であ

るが，神経刺激症状を伴うものはまれである．われわ

れは総腓骨神経刺激症状を伴った膝窩囊腫の一例を経

験したので若干の文献的考察を加えて報告する.
症例

症例 : 45 歳女性.

主訴：左膝外側の疼痛ならびに左下腿外側のしびれ。

現病歴 : 2 年前より左膝後外側に腫瘤を自覚し前医 を受診した．その後腫瘤は次第に増大し，2 ケ月前よ りしゃがみこみ時に下腿外側の痺れ感を自覚するよう になった為, 当科外来を受診し, 精査加療目的にて入

\footnotetext{
* 熊本大学大学院医学薬学研究部運動骨格病態学分野 Department of Orthopaedic and Neuro-Musculoskeletal Surgery, Faculty of Medical and Pharmaceutical Sciences, Kumamoto University, Kumamoto, Japan
} 
院となった.

理学所見 : 左膝に腫脹・熱感・膝蓋跳動はなく, 可 動域は $0 \sim 145^{\circ}$ であった。左膝後外側に $3.5 \times 4 \mathrm{~cm}$ の弾性軟で可動性良好な腫瘤を触知した。伸展位で明 らかな感覚低下, 運動麻痺はなく, 最大屈曲時に下腿 外側のしびれが増強した。囊胞穿刺を行い，穿刺液は 黄色透明な粘稠性のある液体で $13 \mathrm{ml}$ 吸引し, 穿刺後
症状は完全に消失した.

画像所見：左膝単純 $\mathrm{X}$ 線像では異常はみられなかつ た，MRI では膝関節外側の矢状断像にて T2 強調画 像で膝窩部に $5 \times 3 \times 3 \mathrm{~cm}$ の high intensity を示す 内部が均一な腫瘤性病変を認めた（図 $1 \mathrm{a}$ )。水平断 像にて腫瘤は膝窩筋腱と腓腹筋外側頭との間から, 外 側側副勒带まで連続して認められ，総腓骨神経は腫瘤
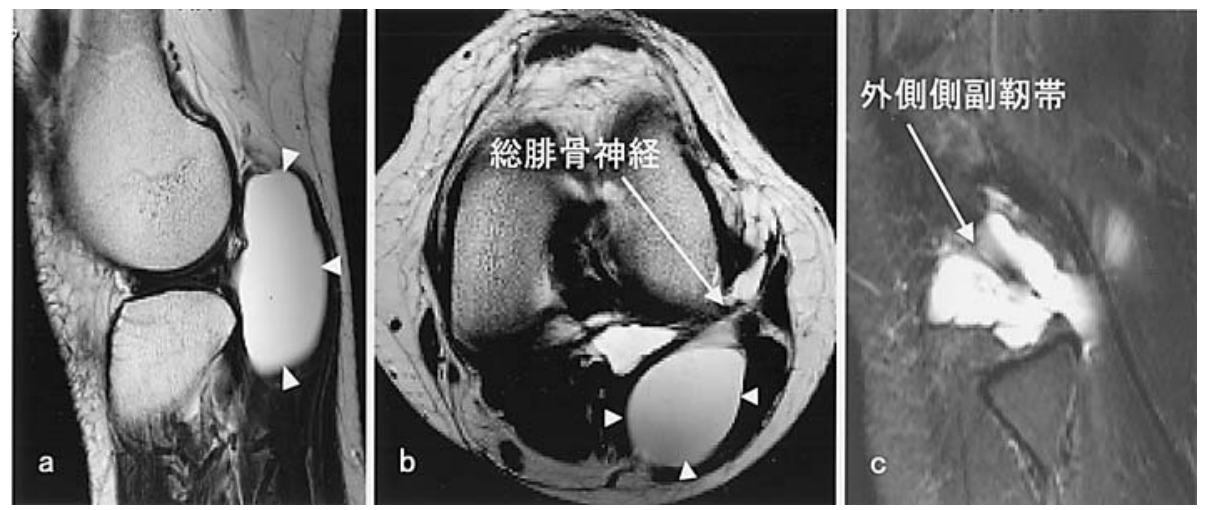

図 1 MRI 画像

a）膝関節外側の T2 強調画像の矢状断では膝窩部に $5 \times 3 \times 3 \mathrm{~cm}$ の high intensity を示す内部が均一な腫瘤性病変を認めた。

b) $\mathrm{T} 2$ 強調画像水平断では腫瘤は膝窝筋腱と腓腹筋外側頭との間から, 外側側副 勒带まで連続して認められ, 総腓骨神経は腫瘤に前後を挟まれるように存在し ていた.

c） STIR 画像で腫瘤は外側側副靶带の内側に位置していた.
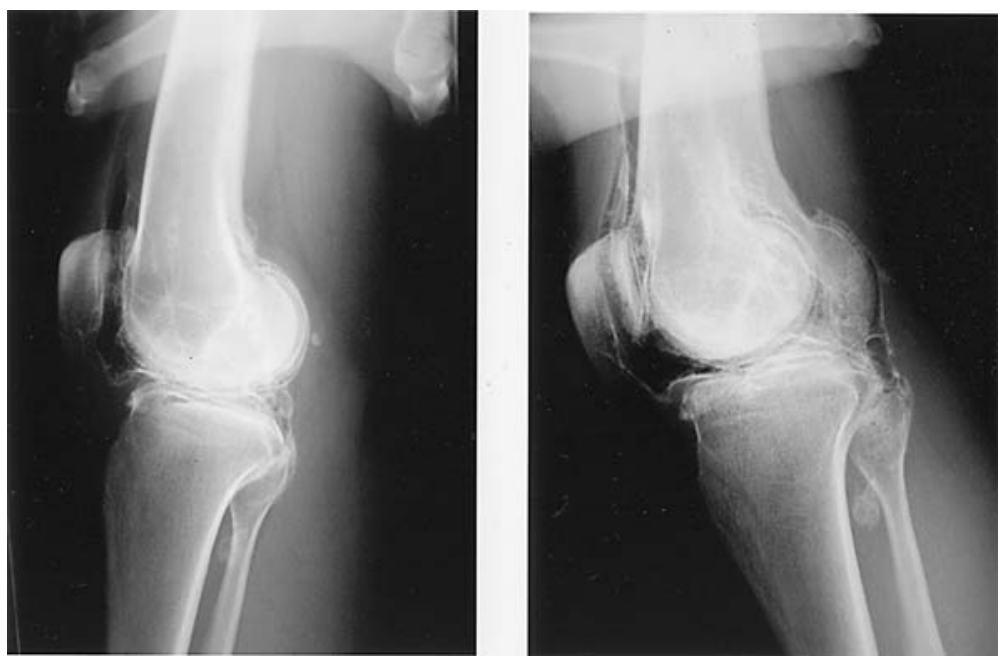

図 2 関節造影像（空気二重造影）

膝窩筋溝への造影剂の流出はみられたが，囊腫内への流出はなく，囊腫と関節内と の明らかな交通はみられなかった。 
に前後を挟まれるように存在していた（図 1 b). STIR 像で腫瘤は外側側副勒帯の内側に位置していた (図 1c)。半月板に明らかな損傷は認められなかった. 空気二重造影法を用いた関節造影検查では，膝窩筋溝 への造影剂の流出はみられたが，囊腫内への流出はな く, 囊腫と関節内との明らかな交通はみられなかった (図 2)。以上より膝窩囊腫と診断し, 関節内との交通 が確認されなかったこと, 総腓骨神経刺激症状があっ たことから, 直視下囊腫摘出術を施行した.

術中所見：総腓骨神経を同定し，腓腹筋外側頭より 中央を展開して白色の腫瘤を直視下に摘出した（図 3).
摘出腫瘤には交通路となる茎は認められず，関節腔と の明らかな連続性は確認できなかった。

病理所見：囊腫は単胞性で, 内壁に扁平化した滑膜 上皮を認め, 炎症細胞浸潤は軽度であった。肥厚した 線維性結合織と外側には血管増生が認められた。病理 診断でも膝窩囊腫であった（図 4).

術翌日より最大屈曲時の下腿外側の痺れは軽快し, 術後 1 ケ月よりしゃがみ込夕での農作業も可能となつ た. 術後 6 ヶ月の時点で左膝後外側の腫脹は消失し, MRI でも再発は認めていない.

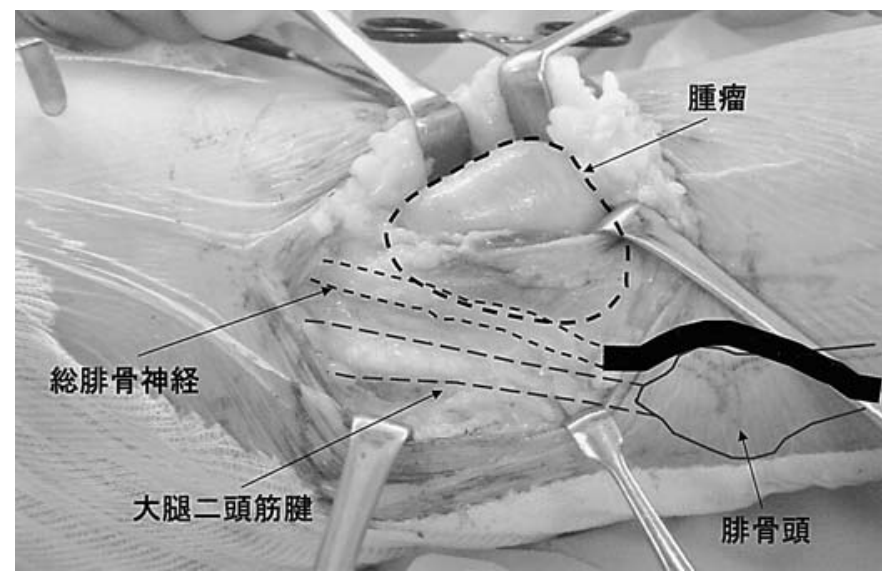

図 3 術中所見

囊腫は膝下筋腱滑液包から発生しており, 総腓骨神経に接していた. 囊腫摘出時関節内との交通路はみられなかった.

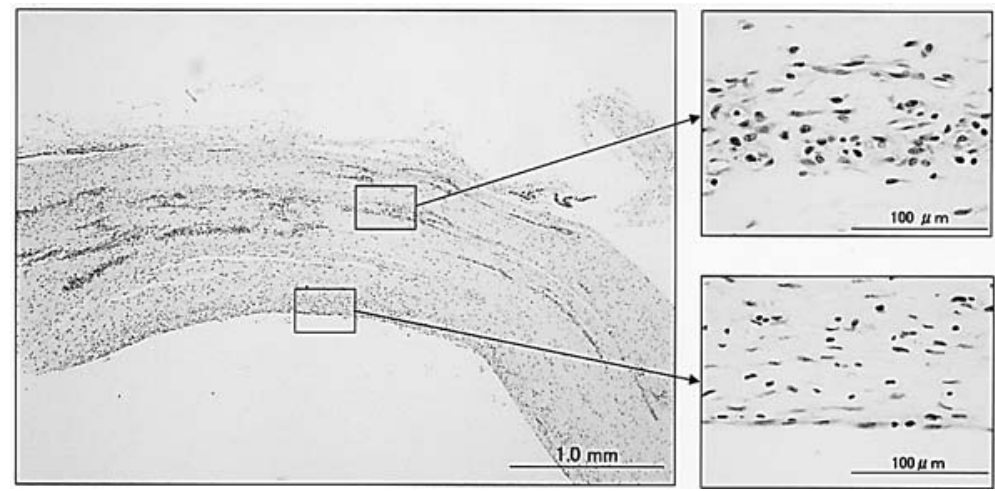

図 4 病理所見

囊腫は単胞性で, 内壁に扁平化した滑膜細胞（lining cell）を認め, 軽度の炎症細胞浸潤を伴う肥厚した線維性結合織と血管増生が認め られ, 膝窩囊腫と診断した. 


\section{考察}

膝窩部に発生する悪性腫瘍を除いた囊胞性病変の分 類には解剖学的分類と臨床病理学的分類が提唱されて いる. 解剖学的分類 ${ }^{6}$ では膝窩囊腫とガングリオン 囊腫に分類され，半月板囊腫はガングリオン囊腫の亜 型とされる. 広義の Baker 囊腫は膝窩囊腫と同義と され，膝窩部の滑液包が囊腫を形成したものをさす が，狭義の Baker 囊腫は腓腹筋一半膜様筋滑液包 (gastrocnemio-semimembranosus bursa) が腫脹し たものをさす． 臨床病理学的分類 ${ }^{2)}$ では関節腔との交 通の有無により分類され，交通がないものを一次性， 交通があるものを 2 次性としている．自験例は MRI と関節造影検査により関節腔との交通は認めておらず, 1 次性でその他の膝窩囊腫に分類されるものと考えら れる.

自験例の腫瘤は外側側副靭帯の内側で膝窩筋腱に接 しており, 外側側副勒帯一膝窩筋腱滑液包が膨隆し, 膝屈曲により腫瘤が後外方に存在する総腓骨神経を圧 迫し刺激症状を呈したと考えられる．囊腫による総腓 骨神経障害の報告については，我々が渉猟しえた限り 1978 年の Nakano らの報告 ${ }^{4)}$ 以来 7 例報告されてい

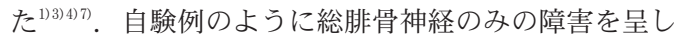
た症例の報告は 3 例のみでありまれといえる.

本疾患に対する治療法については, 穿刺やステロイ ド注入などの保存的治療に抵抗性の症例が手術療法の 適応となるが，関節内と交通があるものには関節鏡手 術が有効とされる ${ }^{5)}$. 関節内と交通が明らかでないも
のや神経症状を呈している症例では囊腫摘出術が一般 的に行なわれている. 本症例においても囊腫と関節内 との交通がないことが確認されたため，我々は囊腫摘 出術を施行し良好な結果が得られた。

結語

外側側副勒帯一膝窩筋腱滑液包から生じ, 総腓骨神 経刺激症状を呈した膝窩囊腫の一例について報告した.

\section{参 考 文 献}

1) Daneyemez, M., et al.: Nerve entrapment by a firmly wrapped Baker cyst. Minim. Invas. Neurosurg., $41: 172-174,1998$.

2) Fritschy, D., et al.: The popliteal cyst. Knee Surg. Sports Traumatol. Arthrosc., 14 : 623-628, 2006.

3) Ji, J., et al.: Compressive neuropathy of the tibial nerve and peroneal nerve by a Baker's cyst. The Knee, $14:$ 249-252, 2007.

4) Nakano, K. K.: Entrapment neuropathy from Baker's cyst. JAMA, 239 : 135-139, 1978.

5) Sansone, V., de Ponti, A.: Arthroscopic treatment of popliteal cyst and associated intraarticular knee disorders in adults. Arthroscopy: The Journal of Arthroscopic and Related Surgery, $15: 368-372$, 1999.

6) Scott, W. N.: Anatomic Aberrations. In Surgery of the Knee Forth Edition, pp.67-85. Edited by Scott, W. N., New York, Churchill Livingstone, 2006.

7) Zygmunt, S., Keller, K., Lidgren, L.: Baker cyst causing nerve entrapment. Scand. J. Rheumatol., 11 : 239-240, 1982. 